\title{
Gastropod Diversity in the Pandayangan River, South Labuhanbatu Regency
}

\author{
Alex Parmonangan Tobing ${ }^{1}$, Arman Harahap ${ }^{2}$ \\ ${ }^{1,2}$ Universitas Labuhanbatu, Indonesia \\ armanhrp82@yahoo.co.id
}

\section{Abstract}

This study aims to determine the diversity of Gastropods in the Pandayangan River, South Labuhanbatu Regency. Descriptive exploratory research was conducted at 3 stations from December to February 2021. Gastropod samples were taken from the sampling results at the time of the study in the Pandayangan River. Samples were taken from 3 stations with different characteristics, the gastropods were washed and documented. The identification process is carried out using the identification key of the Jutting book. The results obtained 7 types of Gastropods from 3 families of Thiaridae, Ampullariidae and Viviparidae, namely Brotia castula, Melanoides tuberculata, Melanoides punctate, Pomacea canaliculata, Pila polita, Pila ampullacea and Filopaludina sumatrensis. Gastropods catch 230 individuals. Station I found 40 individuals, Station II was found 80 individuals and Station III was found 110 individuals. Types of Brotia castula, Melanoides punctate, and Pomacea canaliculata were mostly found at Station II and Station III.

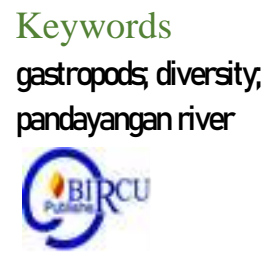

\section{Introduction}

The river has a long flow as the main source of life by humans. Like bathing, washing, and so on as a livelihood. Rivers that flow and reach into each region make the river as a path to move from one place to another. The movement will form a structure of life that makes a settlement that initially the area was uninhabited, and became a fairly large settlement. (Shinta et al, 2020)

South Labuhanbatu Regency is one of the regencies in North Sumatra Province, Indonesia. Based on data from the Central Statistics Agency (BPS) of South Labuhanbatu Regency, the Pandayangan River lives various types of aquatic biota, one of which is Gastropods.

Based on the results of interviews with the local community, the Pandayang River is used for various activities, one of which is a source of livelihood because there are still many aquatic biotas in the Pandayangan River. But the Pandayangan River has started to become polluted due to household domestic waste. Changes in the physical and chemical properties of the waters will change the habitat conditions in these waters to become polluted and cause disruption of the Gastropods.

Gastropods are a group of soft-bodied invertebrates that walk on abdominal legs and generally have shells. These animals are commonly known as snails or slugs. Ecologically Gastropods have an important role in the food chain in freshwater ecosystems, because generally they are hebivores, carnivores, detritivores, deposit feeders, suspension feeders, and parasites, most of which are detrituds and litter from fallen leaves and circulate suspended 
substances. In the water to get food, moss and various algae. Several types of gastropods are commonly consumed by humans as food (Rusyana, 2011)

One of the urgent things to do in Indonesia in aligning health development in order to reach a high degree of health is the problem of stunting. In this connection health development has an integral meaning in relation to the development of human resources in realizing an advanced and independent nation and in physical and spiritual well-being. The current global challenges also revise the health system in Indonesia. From this condition, supporting health development is carried out with the support of a good system and human resources equipped with technological support. In the ideal level those outcomes as a desire in the desired health development efforts, so that from this context sustainability will continue to exist. In the formulation made by WHO provides an understanding that the health system (health system) is all activities that have the aim to improve, improve or care for health (Shinta et al, 2020).

Research on Gastropods has been widely carried out in various regions in Indonesia. Some of these studies are Gastropod research in Lake Kerinci found 8 species (Hamidah, 2000), 3 species in the Musi River (Setiawan, 2010) and 9 species in Lake Kerinci (Sari, 2016). This is based on the description above, the author wants to do research with the title "Gastropod Diversity in the Pandayangan River, South Labuhanbatu Regency".

\section{Research Methods}

\subsection{Research Design}

LabuhanBatu Selatan Regency is one of the districts in North Sumatra Province, Indonesia. The area of North Sumatra Province is recorded 72,981 km2 divided into land area7,298,123 km2 and area of waters11,000,000 km2 (Government of North Sumatra Province, 2013). General water areas in the form of rivers, lakes, swamps, and other standing water (DKP, 2013)

Silangkitang District is one of the districts in South LabuhanBatu Regency. Based on data from the Central Statistics Agency (BPS) of South LabuhanBatu Regency, the area of Silangkitang District is $303.70 \mathrm{~km} 2$. The Pandayangan river is a river basin which has a width of approximately 20 meters and a maximum depth of 10 meters (PPSP, 2012). In the Pandayangan river, there are various types of aquatic biota, one of which is Gastropods.

This study uses a descriptive exploratory method. Observations are made directly by observing the presence of Gastropods in the Pandayangan River waters to obtain data. The sampling location is located on the Pandayangan River with three different observation stations based on environmental conditions that lack community activity and community activity.

Sampling stations are divided into 3 stations located at several representative points around the Pandayangan river. The coordinates of each station for the research location are Station I: Latitude (1'52'38. 41 "U) and Longitude (99 57'13. 14" T), Station II: Latitude $\left(1^{\circ} 52^{\prime} 37.43\right.$ "U) and Longitude (99 $57^{\circ} 11.03$ "E), Station III: Latitude (152'33. 30" U) and Longitude (9957'16. 10 "E). 


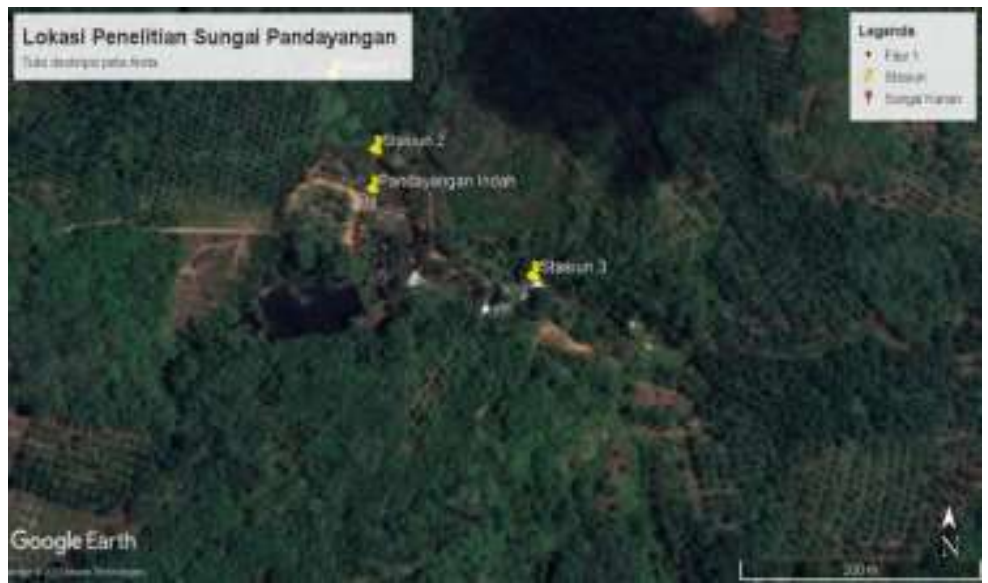

Figure 1. Map of research locations

On each transect, 3 squared plots are placed, with a plot size of $2 \mathrm{~m}$, while the distance between the transects is $10 \mathrm{~m}$. Water physical factors were measured temperature, brightness, current velocity and depth, while chemical factors measured were $\mathrm{pH}$, dissolved oxygen (DO), Biochemical Oxygen Demand (BOD), and type of substrate.

\subsection{Tools and Materials}

The tools used in this study were wooden stakes, raffia ropes, sample bottles, thermometer, $\mathrm{pH}$, stationery, label paper, cameras, gauges and modified gutters, sieves, dykes, and grabs. The materials used in this study were $70 \%$ alcohol, $\mathrm{MnSO} 4, \mathrm{NaOH}$, starch indicators, $\mathrm{H} 2 \mathrm{SO} 4$, and $\mathrm{NaS} 203$.

\subsection{Research Procedure}

a. Preparation Phase

Researchers conducted an initial survey directly in the Pandayangan River, South Labuhanbatu Regency. To determine the existence of gastropods, then make a research design including determining the station and plot. Furthermore, conducting literature studies and provision of tools and materials.

\section{b. Sampling Stage}

Samples found on the substrate attached to rock, mud, sand and wood (within the plots) were taken entirely. Gastropods were counted and put into sample bottles, then given an identity with label paper and then recorded their initial state, documented then preserved and identified in the laboratory. Use $70 \%$ alcohol. After that the sample is taken to the laboratory to be identified and put into a sample bottle for identification.

\subsection{Time and Place of Research}

This research was conducted in the Pandayangan river, South Labuhanbatu district, for three months effectively in the field, starting from December 2020 - February 2021. 


\section{Result and Discussion}

\subsection{Types and Number of Gastropods}

Based on the results of sampling Gastropods at 3 stations in the waters of the Pandayangan River, 7 types of gastropods were obtained from 3 families with a total of 230 individuals. The types and numbers of gastropods at each station are presented in Table 1

Table 1. Types and Number of Gastropods at each station

\begin{tabular}{|c|c|c|c|c|c|c|}
\hline \multirow[t]{2}{*}{ No. } & \multirow[t]{2}{*}{ Family } & \multirow[t]{2}{*}{ Type } & \multicolumn{3}{|c|}{$\begin{array}{c}\text { Number (Individual) at } \\
\text { each station }\end{array}$} & \multirow{2}{*}{$\begin{array}{c}\text { Number of } \\
\text { Individuals } \\
\text { per station }\end{array}$} \\
\hline & & & I & II & III & \\
\hline \multirow{3}{*}{1.} & \multirow{3}{*}{ Thiaridae } & Brotia castula & 20 & 15 & 58 & 93 \\
\hline & & Melanoides tuberculata & 10 & 4 & 8 & 22 \\
\hline & & Melanoides punctata & 10 & 0 & 20 & 30 \\
\hline \multirow[t]{3}{*}{2.} & \multirow[t]{3}{*}{ Ampullariidae } & Pomacea canaliculata & 0 & 20 & 14 & 34 \\
\hline & & Pila polita & 0 & 9 & 2 & 11 \\
\hline & & Pila ampullacea & 0 & 17 & 3 & 20 \\
\hline 3. & Viviparidae & Filopaludina sumatrensis & 0 & 15 & 0 & 20 \\
\hline \multicolumn{3}{|r|}{ amount } & 40 & 80 & 110 & 230 \\
\hline
\end{tabular}

Based on the identification of samples obtained at the time of the study, it can be seen that the number of Gastropods that were found mostly from the Thiaridae family obtained 93 individuals of Brotia castula, 30 individuals of Melanoides punctatea and 34 individuals of Pomacea canaliculata with a total of 230 individuals. According to Sari (2016) this species is the most widely distributed and can be found in every observation station with different habitats.

The large numbers of individual Gastropods from the Thiaridae family were found due to their food availability in the form of detritus, moss, and various algae. Another factor that affects the large number of individuals from the Thiaridae family is that they can live in calm waters, slow-flowing waters and fast-flowing waters. In addition, the Thiaridae family can live in waters with a high content of turbidity and a high TSS (Total Suspended Solid) (Djajasasmita, 1985). The family of Viviparidae can live in swamps, rivers, ponds and lakes that are calm and watery. swift, and live in groups in their habitat (Marwoto and Nurinsiyah, 2009).

\subsection{Diversity Index}

The diversity index value at the three stations ranged from 1.07 to 1.53 . These results indicate that in the waters of the Tabir River, Tabir District, Merangin Regency, the Gastropod diversity index value is low because it is less than 1.5 can be seen in Table 2 .

Table 2. Species diversity index

\begin{tabular}{|c|l|c|}
\hline No. & \multicolumn{1}{|c|}{ Station } & Species Diversity Index $\left(\mathrm{H}^{\prime}\right)$ \\
\hline 1 & Station I & 1.07 \\
2 & Station II & 1.53 \\
3 & Station III & 1.40 \\
\hline
\end{tabular}


Based on Table 2, it can be seen that the diversity of gastropods in the waters of the Pandayangan River, South Labuhanbatu Regency can be seen from the species diversity index of less than 1.5. This is due to the large number of community activities around the waters of the Pandayangan River, such as the disposal of liquid or solid waste, both from households and industries, which can pollute the water so that its quality decreases, the influence of weather during research and the presence of gold mining activities that cause conditions around the waters to be polluted.

\subsection{Dominance}

Data regarding the dominance index at the three stations can be seen in Table 3

Table 3. Dominance Index

\begin{tabular}{|c|l|l|}
\hline No. & \multicolumn{1}{|c|}{ Station } & Dominance index \\
\hline 1 & Station I & 0.33 \\
2 & Station II & 0.21 \\
3 & Station III & 0.42 \\
\hline
\end{tabular}

Based on Table 3, it shows that there is no type that dominates the three stations, because the dominance index value is $<0.5$. At station III, the type of Gastropods, Brotia castula, were found mostly with 50 individuals. Although the number of Gastropods is large, they do not dominate.

\subsection{Description of the Characteristics of Gastropods}

Based on the identification results of Gastropods at 3 stations in the waters of the Pandayangan river, Labuhanbatu Regency, there were 7 types of Gastropods from 3 families, namely: Thiaridae, Ampullariidae and Viviparidae. Gastropod description can be seen below:

Table 4. Description of Gastropods in the Pandayangan River, South Labuhanbatu Regency

\begin{tabular}{|c|l|}
\hline $\begin{array}{c}\text { Family: Thiaridae } \\
\text { Melanoides tuberculata }\end{array}$ & \multicolumn{1}{|c|}{ Brotia costula } \\
\hline $\begin{array}{l}\text { The shell is 30-40 mm tall, has a fragile apex, } \\
\text { the threads on the top are eroded and the last } \\
\text { sizable body whorls. The color of the shell is } \\
\text { brown and black, the surface of the shell is } \\
\text { smooth and has transparent vertical stripes, the } \\
\text { suture is clearly visible and the (aperture) of } \\
\text { the shell mouth is rounded at the bottom and } \\
\text { tapered at the top, the umbilicus is closed } \\
\text { transparent, blackish brown in color. The } \\
\text { (Jutting, 1956) }\end{array}$ & $\begin{array}{l}\text { lop the shell is mostly eroded, the } \\
\text { upright, knit blunt or sharp. These ribs } \\
\text { can be less pronounced, or not ribbed at } \\
\text { all. The mouth of the shell (aperture) is } \\
\text { almost vertical, with a broad oval } \\
\text { (Jutting, 1956) }\end{array}$ \\
\hline
\end{tabular}




\begin{tabular}{|c|c|}
\hline $\begin{array}{l}\text { Family: Ampullariidae } \\
\text { Pomacea canaliculata }\end{array}$ & Pila Polita \\
\hline $\begin{array}{l}\text { Gastropod types found on muddy substrates. } \\
\text { Shell height } 43-53 \mathrm{~mm} \text {. Generally, the shell is } \\
\text { rounded, slightly thin or transparent, the color } \\
\text { of the shell is yellowish or dark brown with the } \\
\text { decoration of brown circular belts that are } \\
\text { more clearly visible on the inside of the shell } \\
\text { (aperture). The umbilicus is open and the end } \\
\text { (body whorls) is large and bloated. } \\
\text { (Djajasasmita, 1999) }\end{array}$ & $\begin{array}{l}\text { Types of gastropods found on muddy } \\
\text { substrates. Shell height } 15-20 \text { mm. } \\
\text { generally the shell is rounded, slightly } \\
\text { thin or transparent, the shell color is } \\
\text { yellow and yellowish green with brown } \\
\text { circular belts that are more clearly } \\
\text { visible on the inside of the shell } \\
\text { (aperture) (Marwoto et al., 2011) }\end{array}$ \\
\hline
\end{tabular}

\subsection{Physical and Chemical Parameter Data}

In this study, observations of the parameters of the aquatic environment consisted of physical and chemical factors. The results of observations of the freshwater gastropod habitat in the Pandayangan River show that there are differences in the parameter values of each station that can be seen in Table 6 .

Table 6. Value of Physical and Chemical Factors at Each Observation Station

\begin{tabular}{|c|c|c|c|c|c|c|}
\hline \multirow[t]{2}{*}{ No. } & \multirow[t]{2}{*}{ Parameter } & \multirow[t]{2}{*}{ Unit } & \multicolumn{3}{|c|}{ Station } & \multirow{2}{*}{$\begin{array}{l}\text { Quality standards } \\
\text { PP No. } 82 \text { Year } \\
2001 \text { (class III) }\end{array}$} \\
\hline & & & I & II & III & \\
\hline \multicolumn{7}{|c|}{ Physics } \\
\hline 1 & Temperature & ${ }^{\circ} \mathrm{C}$ & $28-30$ & $27-29$ & $29-30$ & - \\
\hline 2 & Brightness & $\mathrm{cm}$ & 15 & 7 & 16 & - \\
\hline 3 & Speed & $\mathrm{Cm} / \mathrm{s}$ & 15 & 13 & 8 & - \\
\hline 4 & Depth & $\mathrm{M}$ & $3-4$ & $2-3$ & 1 & - \\
\hline \multicolumn{7}{|c|}{ Chemistry } \\
\hline 1 & $\mathrm{pH}$ & Unit & 6 & 7 & 7 & $6-9$ \\
\hline 2 & DO & $\mathrm{mg} / \mathrm{I}$ & 4,8 & 5.78 & 6.87 & $>3$ \\
\hline 3 & BOD & $\mathrm{mg} / \mathrm{I}$ & 20 & 14.7 & 14.5 & $<6$ \\
\hline 4 & $\begin{array}{l}\text { Type of } \\
\text { substrate }\end{array}$ & $\%$ & $\begin{array}{l}\text { dust } \\
(52.59)\end{array}$ & $\begin{array}{l}\text { sand } \\
(90.89)\end{array}$ & $\begin{array}{l}\text { Sand } \\
(94.56)\end{array}$ & - \\
\hline
\end{tabular}

Based on observations at each station, temperature values were obtained ranging from 25-300C. The highest temperature is at station I and station III, namely $29-30^{\circ} \mathrm{C}$. Whereas at station II the temperature is the same, which is around $25-26^{\circ} \mathrm{C}$. Freshwater gastropods tolerate temperatures for survival and growth in the range of $20-30^{\circ} \mathrm{C}$. This is because freshwater gastropods can grow very well with temperatures of more than $20^{\circ} \mathrm{C}$ (Hamidah, 2000). 
The measured brightness at the station ranges from $7-15 \mathrm{~cm}$. The overall measured brightness value is low. The highest brightness is measured soil particles and sedimentation so that light penetration does not enter deeper waters (Hamidah, 2000).

The speed of the current plays a role in the spread of organisms in the water. The current velocity at the study site ranged from $8-16 \mathrm{~cm} / \mathrm{s}$. This value includes moderate to fast current speeds. Overall, the measured current velocity affects the habitat of freshwater gastropods, because several types of freshwater gastropods prefer fast currents.

Depth affects the intensity of sunlight into the waters (Nybakken, 1988). This affects the rate of photosynthesis by phytoplankton and the content of organic matter which is the source of food for freshwater gastropods. The depth of a water will affect the number of freshwater gastropods. Generally, the deeper the waters cause fewer Gastropods to live in it.

The degree of acidity $(\mathrm{pH})$ is an important factor that can affect aquatic organisms. The $\mathrm{pH}$ values measured at the three stations during the study were not much different, ranging from 6-7. From the measurement results, the $\mathrm{pH}$ value is classified as neutral and supports the survival of Gastropods. According to Erlindadkk (2014) freshwater gastropods have the ability to tolerate $\mathrm{pH}$ ranges from 6.1 to 7.2.

Dissolved oxygen (DO) is a gas mixed with water in such a way that the smallest part is molecular in size. The DO content at station III still supports the survival of freshwater gastropods, namely $6.88 \mathrm{mg} / 1$. This can happen because at the station there is a lot of photosynthesis by grass on the riverbank. The low DO content at station I, which is $4.8 \mathrm{mg} /$ 1 , is due to the condition of the waters being polluted with organic compounds that enter the water bodies which come from liquid or solid waste, both from households and industries, which can pollute the water so that the quality decreases 1999)

Liquid or solid waste, both from households and industries, can pollute water so that its quality decreases. A decrease in quality due to this waste will reduce DO water and increase BOD (Sukadi, 1999). The measurement results of the BOD content showed that the station had the highest BOD level at station I, namely $20 \mathrm{mg} / 1$. The high BOD content at the station turned out to affect the life of freshwater gastropods.

The substrate is a place of refuge and foraging. The substrate classification is based on the percentage ratio of the content of sand, silt and clay. The type of substrate at station I was classified as dusty with a percentage of $52.59 \%$. This condition causes the substrate type to be dusty. The fine dusty substrate type is not good for the growth of freshwater organisms because it has slow water exchange and can cause a decomposition process that takes place in the substrate under anaerobic conditions. The substrate types at stations II and III were classified as sandy, with a percentage of 90.98 and $94.56 \%$. This condition causes the substrate texture to tend to be coarse; the ability to hold water and nutrients is less than the station (Nykbakken, 1988).

\section{Conclusion}

Based on the results of research on the diversity of Gastropods in the Pandayangan River, South Labuhanbatu Regency, it can be concluded that there are 230 Gastropods caught in the Pandayangan River, from 7 types and 3 families with diversity index ( $\mathrm{H}$ '), namely 1.07-1.53 (Low). Meanwhile, per station, namely station I 1.07, station II 1.53, and station III 1.40. Physico-chemical parameters of Gastropod habitat waters support the life of Gastropods in the Pandayangan River, South Labuhanbatu Regency. 


\section{References}

Djajasasmita, M. (1999. Keong dan Kerang Sawah. Jakarta: Puslitbang Biologi-LIPI.

DKP (Dinas Kelautan dan Perikanan) Provinsi Jambi. (2013). Potensi PerikananTangkap. http://dkp.jambiprov.go.id.

Hamidah, A. (2000). Keanekaragaman dan Kelimpahan Komunitas Moluska di Perairan Bagian Utara Danau Kerinci, Jambi. Thesis. Institut Pertanian Bogor.

Jutting, B.W.S.S. (1956). Systematic Studies on the Non-marine Molusca of the IndoAustralian Archipelago. Trubia, 28(2):259-477.

Marwoto, R. M., dan Nurinsiyah, A., S. (2009).KeanekaragamanKeong Air Tawar Marga Filopaludina di IndonesiadanStatus Taksonominya (Gastropoda: Viviparidae). Prosiding Seminar Nasional Moluska 2"Moluska: Peluang Bisnis dan Konservasi”. Bogor: 11-12 Februari 2009.

Rusyana, A. (2011). Zoologi Invertebrata (Teori dan Praktik). Ciamis: ALFABETA.

Sari, D,P. (2016). Keanekaragaman Gastropoda di Perairan Danau Kerinci Kabupaten Kerinci, Provinsi Jambi. Skripsi. Universitas jambi.

Setiawan, D. (2008). Studi Komunitas Makrozoobenthos di Perairan Sungai Musi Sekitar Kawasan Industri di Hilir Kota Palembang. Prosiding Seminar Nasional Limnologi V tahun 2010.

Shinta, H. et al. (2020). Potential Stunting in Riverside Peoples (Study on Pahandut Urban Village, Palangka Raya City). Budapest International Research and Critics InstituteJournal (BIRCI-Journal). P. 1618-1625. 